\title{
Preliminary assessment of medicinal plants used as antimalarials in the southeastern Venezuelan Amazon
}

\author{
Avaliação preliminar de plantas medicinais usadas como \\ antimaláricos no sudeste amazônico Venezuelano
}

\author{
Alejandro Caraballo ${ }^{\dagger}$, Brigida Caraballo ${ }^{1}$ and Alexis Rodríguez-Acosta ${ }^{2}$
}

\begin{abstract}
Eighteen species of medicinal plants used in the treatment of malaria in Bolívar State, Venezuela were recorded and they belonged to Compositae, Meliaceae, Anacardiaceae, Bixaceae, Boraginaceae, Caricaceae, Cucurbitaceae, Euphorbiaceae, Leguminosae, Myrtaceae, Phytolaccaceae, Plantaginaceae, Scrophulariaceae, Solanaceae and Verbenaceae families. Antimalarial plant activities have been linked to a range of compounds including anthroquinones, berberine, flavonoids, limonoids, naphthquinones, sesquiterpenes, quassinoids, indol and quinoline alkaloids.
\end{abstract}

Key-words: Ethnomedicine. Phytotherapeutic. Medicinal plants. Malaria. Venezuelan amazon.

\section{RESUM0}

Dezoito espécies de plantas medicinais usadas no tratamento da malária no Estado Bolívar, Venezuela, foram estabelecidas e pertenciam às familias Compositae, Meliaceae, Anacardiaceae, Bixaceae, Boraginaceae, Caricaceae, Cucurbitaceae, Euphorbiaceae, Leguminosae, Myrtaceae, Phytolaccaceae, Plantaginaceae, Scrophulariaceae, Solanaceae e Verbenaceae. As atividades antimaláricas destas plantas parecem estar ligadas a um grupo de compostos que incluem antroquinonas, berberina, flavonoides, limonoides, naftquinonas, sesquiterpenos, quassinoides, indol e alcalóides de quinolina.

Palavras-chaves: Etnomedicina. Fitoterapêutica. Plantas medicinais. Malária. Amazonas Venezuelano.

Malaria is the mostimportantand devastating parasitic infection in the world ${ }^{1623}$. Malaria cases are frequently recorded in Bolívar state territory, which comprises sweeping grassy plains, as well as areas along the Orinoco River and tropical forests inhabited by gold and diamond miners. The area is also inhabited by near nineteen Amerindian groups who live scattered throughout the jungle and highlands. For several years, the standard antimalarial drugs which include quinoline derivates, sulpha drugs and antifolates have been employed in the treatment of malaria by the National Malaria Control Program. Preparations based on plants used in traditional medicine have been widely employed in the Bolivar State as an alternative to pharmaceutical ${ }^{14}$.

The Amazon has not been botanically explored as have the savannas, scrublands, the surrounding lowland and upland forest and even mountains, most of which are now considered to be intensively studied and therefore taxonomically known ${ }^{14}$. As part of a project aimed at improving the antimalarial therapeutics in Venezuela, we organized a ethnobotanical survey on traditional medicinal plants used in the treatment of malaria in Bolívar State, Venezuela. During 5 years this study was conducted in Bolívar State, in a tropical humid forest area at Domingo Sifontes municipality. This southeastern area ( $\left.65000 \mathrm{~km}^{2}\right)$ of the state is the most densely populated region and is situated at $07^{\circ} 15^{\prime}$ Nlatitude and $61^{\circ} 26^{\prime}$ W longitude ${ }^{15}$. Data were obtained using standard ethnobotanical collecting techniques ${ }^{19}$. The information was collected from Kariña, Akawayo, North Arawak Amerindians and miner population. Three regions were explored: Tumeremo (capital of the Domingo Sifontes municipality), El Dorado and Las Claritas. The most knowledgeable members of each community were identified and interviewed. The basic question underlying the interviews was "do you use any plants to treat or to cure malaria"? Specimens of the plants used were then collected in the field with the informants, and details of their modes of preparation,

\footnotetext{
1. Departamento de Botánica, Facultad de Agronomía, Universidad del Zulia, Apartado Postal 526, Maracaibo, Venezuela. 2. Instituto de Medicina Tropical, Universidad Central de Venezuela, Apartado Postal 47423-Caracas 1041A, Venezuela.

'This paper is dedicated In memoriam of Dr. Alejandro Caraballo who died while this work was being finishing.

Address to: Dr. Alexis Rodríguez-Acosta. Apartado 47423, Caracas 1041, Venezuela.

e-mail: rodriguf@ucv.ve

Recebido para publicação em 7/4/2003

Aceito em 12/1/2004
} 
Table 1 - Some plants used in the treatment of malaria in the Domingo Sifontes municipality, Bolivar State, Venezuela.

\begin{tabular}{|c|c|c|c|c|c|}
\hline \multirow{2}{*}{$\begin{array}{l}\text { Bolívar State data } \\
\text { Species }\end{array}$} & \multirow[b]{2}{*}{ Family } & \multirow[b]{2}{*}{ PU } & \multicolumn{2}{|r|}{ Comparative data } & \multirow[b]{2}{*}{ Details } \\
\hline & & & $\mathrm{PP}$ & species & \\
\hline Azadirachta indica A.Juss. & Meliaceae & 1 & $\mathrm{~d}$ & Azadirachta indica A.Juss & Used to treat malaria in India and Sudan ${ }^{39}$ \\
\hline Bixa orellana L. & Bixacea & $1, \mathrm{r}$ & $\mathrm{d}$ & Bixa orellana & Used to treat malaria in Brazil and Peru ${ }^{8} 18$ \\
\hline Carica papaya L & Caricaceae & $\mathrm{At}$ & j & Carica papaya & Used to treat malaria in Brazil an Surinam ${ }^{1819}$ \\
\hline Cedrela odorata L. & Meliaceae & $\mathrm{sb}$ & mwv & Cedrela odorata & Used to treat malaria elsewhere ${ }^{12}$ \\
\hline Eucalyptus globulus Labill. & Myrtacea & 1 & $d$ & Eucalyptus globulus & Used to treat malaria in Venezuela ${ }^{1213}$ \\
\hline Heliotropium indicum L. & Boraginaceae & 1 & $\mathrm{~d}$ & Heliotropium indicum & Used to treat malaria in Venezuela ${ }^{1}$ \\
\hline Momordica charantia L. & Cucurbitaceae & 1 & $d$ & Momordica charantia & $\begin{array}{l}\text { Used to treat malaria in Brazil, Colombia, Guyana, } \\
\text { Trinidad, WestIndies, and Venezuelala }{ }^{14} 1213172024\end{array}$ \\
\hline Parthenium hysterophorus L. & Compositae & $\mathrm{r}$ & $d$ & Parthenium hysterophorus & Used to treat malaria in Venezuela ${ }^{1}$ \\
\hline Petiveria alliacea L. & Phytolaccaceae & Ep & $d$ & Petiveria alliacea & Used to treat malaria in Brazil ${ }^{80}$ \\
\hline Phyllanthus niruri $\mathrm{L}$. & & & & $\begin{array}{l}\text { Phyllanthus niruri and } \\
\text { Phyllanthus niruri spp }\end{array}$ & $\begin{array}{l}\text { P. niruri used to treat malaria elsewhere }{ }^{920} \text { and } \\
\text { other spp Used in Brazil, Cuba and Surinam }{ }^{13} 2021\end{array}$ \\
\hline Plantago australis Lam. & Plantaginaceae & 1 & $d$ & Plantago australis & Used to treat malaria in Venezuela ${ }^{14}$ \\
\hline Scoparia dulcis L. & Scrophulariaceae & $1, r$ & $d$ & Scoparia dulcis & $\begin{array}{l}\text { Used to treat malaria in } \\
\text { Colombia and Venezuela }{ }^{1}{ }_{11} 12\end{array}$ \\
\hline Senna occidentalis L.Link. & Leguminosae & $1, r$ & $d$ & Senna occidentalis & $\begin{array}{l}\text { Used to treat malaria in Brazil, } \\
\text { Colombia and Venezuela }{ }^{2} 578121819\end{array}$ \\
\hline Solanum spp. & Solanacea & ep & $d$ & Solanum spp & $\begin{array}{l}\text { Used very widely to } \\
\text { treat malaria } \\
2021222324\end{array}$ \\
\hline Spondias mombin L. & Anacardiaceae & 1 & $d$ & Spondias mombin & Used to treat malaria in Venezuela ${ }^{1}$ \\
\hline Taraxacum officinale Web. & Compositae & $\mathrm{L}, \mathrm{r}$ & $d$ & Taraxacum officinale & Used to treat malaria in Venezuela ${ }^{1}$ \\
\hline Verbena litoralis H.B.K & Verbenaceae & 1 & $d$ & Verbena litoralis & Used to treat malaria in Venezuela ${ }^{1}$ \\
\hline Vernonia spp & Compositae & $\mathrm{sb}$ & $d$ & Vernonia spp & $\begin{array}{l}\text { Used to treat malaria in Brazil, } \\
\text { Colombia and Venezuela } 71220\end{array}$ \\
\hline
\end{tabular}

administration and use were recorded, as well as local names and any other relevant data. Information was double-checked with more than one interviewee. The standard herbarium specimens were collected for subsequentidentification of the species.

Parts of the plants screened by antimalarial activity were those that people recommended ( roots, leaves, etc). The pieces were air-dried in the dark when possible, but in the sun when the humidity was too high.

Eighteen plants species of 13 families used in the treatment of malaria at Domingo Sifontes Municipality were identified. Details of the use of some of these plants together with comparative data are presented in Table 1.

The plants recorded in this survey, were used in the treatment of the disease and not as prophylactics. The majority were used as decoctions and were generally administered three times daily until malaria was cured. Some plants were used both internally and externally (as baths), and in a few cases they were applied as compresses to the swollen spleen.

The antimalarial activity has been linked to a range of compounds including anthroquinones, berberine, flavonoids, limonoids, naphthquinones, sesquiterpenes, quassinoids, indol and quinoline alkaloids and many of the genera represented by the plants collected in this work have been shown to contain these compounds ${ }^{21}$.

The most frequently used plant parts were: leaves ( $70 \%)$; roots (15\%); fruits (10\%); and stalks (2\%). The enormous frequency of the leaves in traditional compounds is related to their abundant availability and easy collection.

The knowledge of plants used in the treatment of malaria in the Domingo Sifontes municipality, combined with the high level of correlation found with the uses of these plants ( or related species) in diverse parts of Latin America, indicates the inheritance of our ancestors' knowledge in the whole continent. It represents sometimes the only available alternative malaria treatment in remote communities of the municipality and its surroundings.

\section{REFERENCES}

1. Albornoz, A. Medicina Tradicional Herbaria. Instituto Farmacoterápico Latino, Caracas, 1997.

2. Altschul S, Lipp. New Sources for Drugs and Foods from the New New York Botanical Garden Herbaria. Harvard University Press. Cambridge, 1982.

3. Aminuddin RD, Girach A, Subhan KA. Treatment of malaria through herbal drugs from Orissa, India. Fitoterapia 64: 545-548, 1993.

4. Ayensu ES. Medicinal Plants of the West Indies. Reference Publications. Algonac, Michigan, 1981.

5. Brandao MGL, Grandi TSM, Rocha TMM, Sawyer DR, Krettli AU. Survey of medicinal plants used as antimalarials in the Amazon. Journal of Ethnopharmacology 36: 175-182, 1992.

6. Delascio-Chitty F. Algunas Plantas Usadas en la Medicina Empírica Venezolana. Direccion de Investigaciones Biologicas, INPARQUES, Caracas, 1985.

7. Di Stasi LC, Hiruma CC, Guimaraes EM, Santos CM. Medicinal plants popularly used in Brazilian Amazon. Fitoterapia 65: 529-540, 1994. 
8. Duke JA, Vasquez R. Amazonian Ethnobotanical Dictionary. CRC Press. Boca Raton, 1994.

9. El-Kamali HH, El-Khalifa KFTreatment of malaria through herbal drugs in the Central Sudan. Fitoterapia 68: 527-528, 1997.

10. Estrella E. Plantas Medicinales Amazonicas: Realidad e Perspectivas. Tratado de Cooperación Amazonica. Lima, 1995.

11. García-Barriga H. Flora Medicinal de Colombia. Tercer Mundo. Bogotá, 1992.

12. Gil-Otaiza R. Plantas usuales en la Medicina Popular Venezolana. Universidad de los Andes. Merida,Venezuela, 1997.

13. Grenand P, Moretti C, Jacquemin H. Pharmacopées Traditionelles en Guyane. ORSTOM. Paris, 1987.

14. Huber 0 . Estado actual de los conocimientos sobre flora y la vegetación de la región Guayana, Venezuela. In: Weibezahn FH, Alvarez H, Lewis Jr WM (eds) The Orinoco river as ecosystem. CVG-EDELCA, Fondo Editorial Acta Científica, CAVN, USB, Caracas, 1990.

15. Huber O, Alarcón C. Venezuelan Guayana Vegetation Map.CVG-EDELCA and Missouri Botanical Garden, Caracas, 1995
16. Klayman DL. Weeding out malaria. Natural History 10: 18-91, 1989

17. Lachman-White DA, Adams CD, Trotz UOD. A Guide to the Medicinal Plants of Coastal Guyana. Commonwrealth Science Council. London, 1987.

18. Lorenzi H. Plantas Daninhas do Brasil: Terrestres, Aquáticas, Parasitas, Tóxicas e Medicinais. Editora Plantarum. Nova Odessa, 1991.

19. Milliken W. Malaria and antimalarial plants in Roraima, Brazil. Tropical Doctor 27( suppl 1): 20-25, 1997.

20. Morton JF. Atlas of Medicinal Plants of Middle America. C. Thomas. Springfield, Illinois, 1981

21. Phillipson JD, Wright CW. Antiprotozoal agents from plant sources. Planta Medica 57( suppl) : 53-59, 1991.

22. Pittier H. Las Plantas Usuales de Venezuela. Fundación Eugenio Mendoza. Caracas, 1978.

23. Rodriguez-Acosta A, Dominguez NG, Aguilar I, Girón ME. Characterization of Plasmodium falciparum glutamate dehydrogenase-soluble antigen. Brazilian Journal of Medical and Biological Research 31: 1149-1155, 1998.

24. Wong E. Medicinal Plants of Trinidad. Economic Botany Laboratory, USDA, Betsville, 1976. 